\title{
DAMAGE EVALUATION OF PRESTRESSED CONCRETE-PILES BY ACOUSTIC EMISSION
}

\author{
Tomoki SHIOTANI ${ }^{1}$, Mitsuhiro SHIGEISHI ${ }^{2}$ and Masayasu OHTSU³ \\ ${ }^{1}$ Member of JSCE, Ph.D., Senior Research Engineer, Research Institute of Technology, Tobishima Corporation \\ (5472 Kimagase, Sekiyado, Higashi-katsushika, Chiba 270-0222, Japan) \\ ${ }^{2}$ Member of JSCE, Dr. Eng., Associate Professor, Dept. of Civil Eng. \& Architecture, Kumamoto University \\ (2-39-1, Kurokami Kumamoto 860-8555, Japan) \\ ${ }^{3}$ Member of JSCE, Dr. Eng., Professor, Dept. of Civil Eng. \& Architecture, Kumamoto University
}

(2-39-1, Kurokami Kumamoto 860-8555, Japan)

\begin{abstract}
A fundamental study on fracture mechanisms of concrete-piles under both cyclic and monotonic loadings is performed by using acoustic emission techniques. Full-scale prestressed high-strength concrete piles are subjected to bending and shear loadings. Growth of cracks is monitored by $\mathrm{AE}$, and three-dimensional $\mathrm{AE}$ source location is conducted together with identification of crack. These results are compared with results of the pile integrity tests (PIT) and visual observation. It leads to the conclusion that damage inspection by AE is more effective than by PIT in the case where open cracks due to loading would close under unloading. The crack widths evaluated by $\mathrm{AE}$ were remarkably compatible to the results of the wave velocity test.
\end{abstract}

Key Words : acoustic emission, damage evaluation, pile integrity test, prestressed concrete-pile

\section{INTRODUCTION}

The Great Hanshin Earthquake badly hit Japan in 1995. After the quakes, it becomes important to investigate the integrity of structures at the disaster area. Investigation of the superstructure is easily conducted by visual observation, whereas that of substructure, especially pile-foundations installed in deep bearing strata, is substantially difficult. In the pile-foundations, damage degree has been discussed based on existence of cracks, and width of crack, although the relation between them has still unsolved. Even in the technique for investigating cracks, promising techniques have not yet developed. So far, there exist a few methods to investigate the crack conditions of the piles. The pile integrity test $(P I T)^{1)}$, which is a sort of the impact-echo test, has been widely applied ${ }^{2}$. Originally PIT was developed as a test for quality control of piles after completion to check the sufficiency of design lengths. To apply longer piles, instrumentation of PIT is modified for lower frequencies less than $1 \mathrm{kHz}$. As a result, an applicability of PIT is not yet confirmed to investigate integrity of long piles. Acoustic emission
(AE) is known as elastic waves related directly to fracture. As for the fracture process of concrete-piles, AE signals due to both crack initiation and crack growth could be observed ${ }^{3)}$. In damaged concrete-piles, it is also expected that secondary AE signals due to fretting at existing crack surfaces would be released. Paying attention to the secondary $\mathrm{AE}$ signals, an applicability of the $\mathrm{AE}$ technique to diagnosis of concrete-piles has been examined ${ }^{4), 5)}$. Because the previous paper mainly discussed the applicability of the technique to actual piles, fundamental studies on characteristics of $\mathrm{AE}$ waves due to fracture of piles have not been examined. In this report, a fundamental study on fracture mechanisms of the concrete-piles under both cyclic and monotonic loadings is carried out by applying $\mathrm{AE}$ technique. Full-scale prestressed high-strength concrete (PHC) piles are subjected to both bending and shear loads. Growth of cracks is monitored by $\mathrm{AE}$, and three-dimensional $\mathrm{AE}$ source locations are performed, along with crack classification and crack orientation by SiGMA (simplified Green's function for moment tensor analysis $)^{6), 7)}$. These results obtained are compared 
Table 1 Concrete piles tested.

\begin{tabular}{l|l|l|c}
\hline $\begin{array}{l}\text { Type of } \\
\text { failure }\end{array}$ & $\begin{array}{l}\text { Loading } \\
\text { pattern }\end{array}$ & $\begin{array}{l}\text { Level of } \\
\text { damage }\end{array}$ & Name of piles \\
\hline \multirow{3}{*}{ Bending } & Cyclic loading & Heavy & $\mathrm{M} 1$ \\
\cline { 2 - 4 } & $\begin{array}{l}\text { Monotonic } \\
\text { loading }\end{array}$ & Light & $\mathrm{M} 2$ \\
\hline \multirow{3}{*}{ Shear } & $\begin{array}{l}\text { Monotonic } \\
\text { Loading }\end{array}$ & Heavy & $\mathrm{M} 3$ \\
\cline { 2 - 4 } & Cyclic loading & Light & $\mathrm{S} 1$ \\
\hline
\end{tabular}

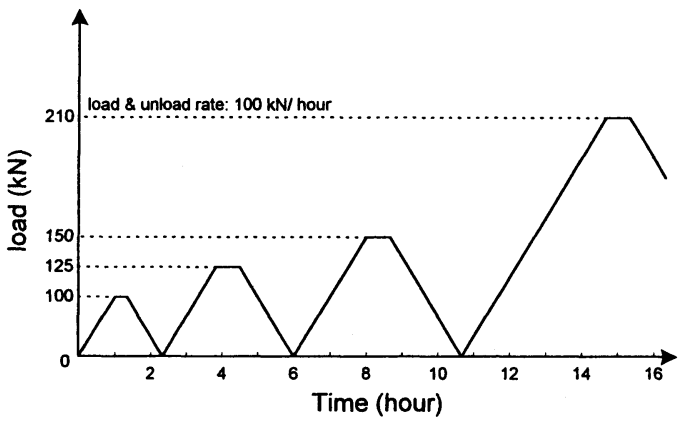

Fig. 1 Loading procedure in Pile M2.

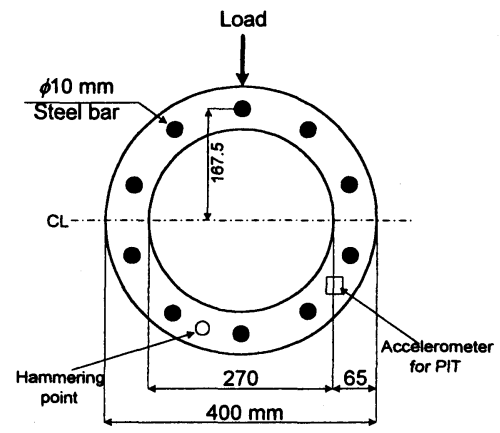

Fig. 2 A cross section of a PHC pile.

with those of PIT. An applicability of AE to evaluation of structural integrity in concrete-piles is demonstrated.

\section{EXPERIMENT}

\section{(1) Specimens and damage level}

Fracture tests were carried out on PHC piles under cyclic and monotonic loadings of both bending and shear. In the cyclic loadings, five loading cycles in the bend and two loading cycles in the shear are repeated. A typical cyclic load application in the bend is shown in Fig. 1. The piles with controled two damage levels of "light" and "heavy" were prepared.
Table 2 Mechanical properties of PHC-B piles.

\begin{tabular}{|c|c|c|}
\hline Applications & Buildings & Road construction \\
\hline $\begin{array}{l}\text { Design } \\
\text { compressive } \\
\text { strength }(\mathrm{MPa})\end{array}$ & over 83.3 & 78.4 \\
\hline \multirow{6}{*}{$\begin{array}{l}\text { Allowable } \\
(\mathrm{MPa})\end{array}$} & \multicolumn{2}{|c|}{ Compression } \\
\hline & $23.5(\mathrm{~L}), 41.7(\mathrm{~S})$ & $22.5(\mathrm{~N}), 33.8(\mathrm{EQ})$ \\
\hline & \multicolumn{2}{|c|}{$\begin{array}{c}\text { Tension } \\
\end{array}$} \\
\hline & $2.0(\mathrm{~L}), 3.9(\mathrm{~S})$ & $\begin{array}{c}0(\mathrm{~N}), 2.9 / 4.9 \\
(\mathrm{EQ})\end{array}$ \\
\hline & \multicolumn{2}{|c|}{ Shear } \\
\hline & 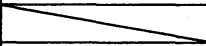 & $0.8(\mathrm{~N}), 1.2(\mathrm{EQ})$ \\
\hline $\begin{array}{l}\text { Young's moduls } \\
\left(\mathrm{N} / \mathrm{mm}^{2}\right)\end{array}$ & 34313.7 & $39215.7 / 34313.7$ \\
\hline
\end{tabular}

Note that the light damage corresponds to the stage where cracks opened due to loading, while close under unloading. In contrast, the heavy damage corresponds to the stage where crack would not close even under load-free conditions. Table 1 summarizes the failure type, the loading pattern and the damage level of concrete piles. Concrete-pile of PHC (pretensioned spun high strength concrete piles) type $B$, which is commercially available, was subjected to the test. The concrete-pile was made of high-strength concrete and pretensionreinforcements based on JIS A 5337, which has dimensions $7 \mathrm{~m}$ long with $400 \mathrm{~mm}$ in outer diameter and $270 \mathrm{~mm}$ in internal diameter as shown in Fig. 2. Ten steel bars to give effective prestress $7.85 \mathrm{~N} / \mathrm{mm}^{2}$ are set equally spaced of $167.5 \mathrm{~mm}$ circumferenctially in radius. Mixture proportions of water (W): cement (C): sand (S): gravel (G) is 163 : 400: 740: 980 by weight in concrete. The concrete-piles were firstly cured in steam, and they were further cured in autoclave. Mechanical properties of the concrete-pile are shown in Table 2.

\section{(2) AE monitoring system and PIT}

Fig. 3 illustrates the setup for bending and shear fracture tests and arrangements of AE sensors. In the figure, distances in the vertical direction are denoted in circumference. Both bending and shear loads were applied by four-point loading. Here, the shear failure was generated by locating the supports close to the loading points. Thus, it was expected that the bending failure would be generated at the zone between the loading points, while the shear failure would appear at the zone between the loading points and the supports. A six-channel LOCAN $320 \mathrm{AE}$ system (PAC) was used for the measurement of conventional AE parameters. AE signals detected by 

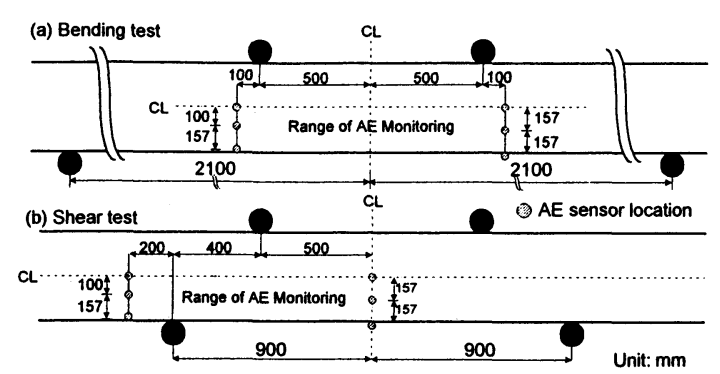

Fig. 3 Illustrations of fracture tests and arrangements of $\mathrm{AE}$ sensors.

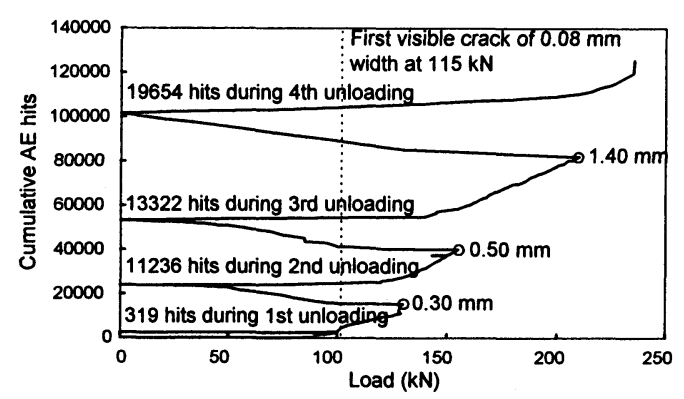

(a) Pile M2 under bending

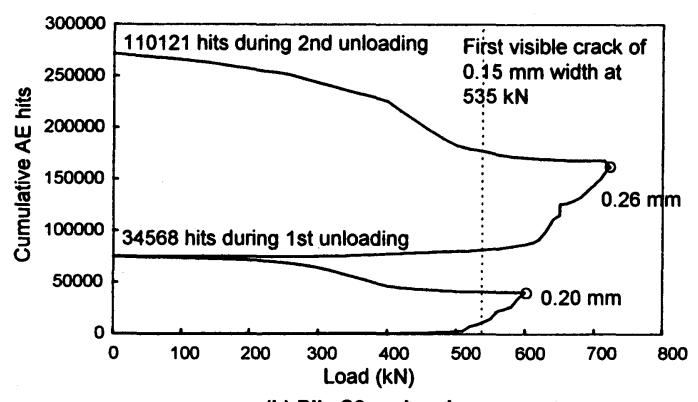

(b) Pile S3 under shear

Fig. 4 Relations between cumualative $\mathrm{AE}$ hits and cyclic loadings.

six sensors, $\mathrm{R} 6$ ( $60 \mathrm{kHz}$ resonance), are amplified by $40 \mathrm{~dB}$ in preamplifiers. The signals were further amplified by $40 \mathrm{~dB}$ in main amplifiers. The signals exceeding $50 \mathrm{~dB}$ were recorded. Since the moment tensor analysis requires a set of six $\mathrm{AE}$ waveforms recorded by six independent channels for each $\mathrm{AE}$ event, a TRA-212 system (PAC) with six TRA cards was employed. Six AE sensors were properly placed on the pile surface as shown in Fig. 3. For bending tests, $\mathrm{AE}$ sensors were set in the middle zone between loading points, while $\mathrm{AE}$ sensors were placed between the supports and the loading points for shear tests.

A pile integrity test (PIT) was performed by using
IT-system (IFCO), where impact and sensor locations of one pile-end were required. An accelerometer was set on the one end of the pile, and a hammer was hit at the other end. These locations, which resulted in the most sensitive locations for damage evaluation in PIT, are also shown in Fig. 2. To set the accelerometer, a putty-couplant was used to have good contact between the transducer and the pile.

\section{RESULTS AND DISCUSSION}

\section{(1) Kaiser effect under cyclic loading}

Fig. 4 shows a relation between cumulative AE hits and the load applied. In pile M2, five loading cycles were repeated, and two loading cycles were applied in pile S3. Dotted lines in the graphs show the loads where the surface cracks were firstly observed, and open circles indicate maximum crack widths observed at the peak loads. In the case of pile M2, approximately $115 \mathrm{kN}$ is the load where cracks start to be observed. In contrast, the onset of visible cracks is over $500 \mathrm{kN}$ in pile $\mathrm{S} 3$. From a relation between the previous load $\left(\mathrm{P}_{\mathrm{p}}\right)$ and the load $\left(\mathrm{P}_{\mathrm{a}}\right)$ where $\mathrm{AE}$ starts to increase at each loading stage, Felicity ratio $\left(\mathrm{P}_{\mathrm{a}} / \mathrm{P}_{\mathrm{p}}\right)$ is obtained as given in Table 3 , where "cumulative $\mathrm{AE}$ ratio" means the ratio of the accumulation of $\mathrm{AE}$ hits under loading to that of unloading. When the piles generates a number of critical microcracks under up-loaing, active $\mathrm{AE}$ generation under unloading is expected due to the slip between reinforcement and the concrete or the friction between crack interfaces. In the next loading, $\mathrm{AE}$ activity is also expected from lower stress level than the previous maximum loads due to new crack propagation. In contrast, $\mathrm{AE}$ activity in the piles of few microcracks is considered to be stable and low at low stress level ${ }^{8)}$. Then, Felicity ratio, which is also called as CBI ratio ${ }^{9)}$ when applying to concre beam, smaller than one corresponds to the damaged state, while the ratio greater than one indicates the sound state. In the AE activity under unloading, several qualititive treatments have been reported ${ }^{\text {9) }}$, however, a quantitative treatement has not been so far introduced. Thus, in this paper, one quantitative method "cumulative $\mathrm{AE}$ ratio" ratio of the accumulation of $\mathrm{AE}$ hits under loading to that of unloading, is proposed. In the case of pile M2, Felicity ratio becomes smaller than one during the third loading. This implies that the pile was damaged during the second loading cycle. The cumulative AE ratio at the second loading cycle is 0.88 , which means that $\mathrm{AE}$ events were comparably generated during the unloading to the loading. Because activity 
of $\mathrm{AE}$ hits under unloading represents unstable states, the damage estimated from Felicity ratio agrees quite well with the results of the cumulative $\mathrm{AE}$ ratio. Thus, it is noted that the cumulative $\mathrm{AE}$ ratio is also effective for the damage evaluation. As for detectable minimum crack width, the $\mathrm{AE}$ technique found that it ranges $0.08-0.30 \mathrm{~mm}$. In the following third and forth loadings, the same trends on both Felicity ratio and the cumulative $\mathrm{AE}$ ratio are observed. As for the pile S3, the detectable minimum crack width by Felicity ratio ranges $0.15-0.20 \mathrm{~mm}$, and it also agrees well with the result of the cumulative $\mathrm{AE}$ ratio in the first cycle. Accordingly, it leads to the fact that the width for the initiation of unstable cracks ranges $0.08-0.30 \mathrm{~mm}$ for bending, and ranges $0.15-0.20 \mathrm{~mm}$ for shear in PHC piles. The ultimate crack width has been elsewhere discussed in reinforced concrete ${ }^{10), 11)}$. They reported that Kaiser effect started to break down and high $\mathrm{AE}$ activities were observed after the opening width of surface crack exceeded $0.12-0.20 \mathrm{~mm}$. Thus, their results on the ultimate crack width of reinforced concrete are in good agreement with our results for prestressed concrete. In the PHC piles, it is known that a crack width smaller than $0.5 \mathrm{~mm}$ under loading would close due to unloading ${ }^{12)}$. It implies that it may be difficult to evaluate structural integrity of the PHC piles from only the surface crack width. By Felicity ratio and the cumulative $\mathrm{AE}$ ratio, structural integrity of the PHC piles can be evaluated.

\section{(2) Moment tensor analysis}

To classify crack types and to determine the crack orientation, a moment tensor analysis for quantitative $\mathrm{AE}$ waveform analysis was applied. $\mathrm{AE}$ data sets consisting of six AE waveforms were recorded during the tests. SiGMA code was applied to analyze the set of the $\mathrm{AE}$ waveforms. From SiGMA analysis, shear ratio $(x)^{13)}$, source location and crack orientation are obtained. Here, a pure shear crack corresponds to the case $x=100$ percent, where the displacement discontinuity vector is perpendicular to the vector normal to the crack surface. In contrast, a pure tensile crack corresponds to the case $x=0$ percent, where the discontinuity vector is parallel to the normal vector. From the values shear ratio $x$, tensile cracks were determined as $\mathrm{AE}$ events with the shear ratio smaller than $40 \%$. Mixed-mode cracks were of those between $40 \%$ and $60 \%$, and shear cracks were of thoese greater than or equal to $60 \%$. The tensile cracks are indicated by arrow symbol $(\leftrightarrow)$, the orientation of which corresponds to the crack opening direction. The shear cracks and the mixed-mode cracks are denoted
Table 3 Chart of Felicity ratio and cumulative $\mathrm{AE}$ ratio in typical results of bending and shear.

\begin{tabular}{l|l|c|c|c|c}
\hline & Loading stage & 1st & 2nd & 3rd & 4th \\
\hline \multirow{3}{*}{ M2 } & Felicity ratio & -- & 1.00 & 0.92 & 0.90 \\
\cline { 2 - 6 } & Cumulative AE ratio & 0.14 & 0.88 & 0.83 & 0.69 \\
\hline \multirow{2}{*}{ S3 } & Felicity ratio & --- & 0.93 & & \\
\cline { 2 - 6 } & Cumulative AE ratio & 0.86 & 0.68 & & \\
\hline
\end{tabular}

by cross symbol (+). Source location is affected by several factors such as wave velocity, anisotoropy of the velocity, sampling rate of wave, crack conditions and so forth. In the case of wave velocity $4000 \mathrm{~m} / \mathrm{s}$ and samling rate $1 \mathrm{MHz}$, for example, the error of source location would be smaller than $4 \mathrm{~mm}$. Fig. 5 shows the results of $\mathrm{AE}$ source locations, crack classification and crack orientation with traced surface cracks at several stages of the bending tests. Fig. 6 shows those of the shear tests. In these figures, $\mathrm{AE}$ sources are projected onto the pile surface.

In pile $\mathrm{M} 1$ resulted in heavily damaged due to cyclic bending load, microcracks are initially generated in the right side of the specimen as shown in M1 (a), which are observed as the visible crack shown in M1 (b). Eventually cracks spread in whole area as shown in M1 (c). In pile M2, microcracks are first observed around the bottom side of the specimen as shown in M2 (a). Then, microcracks are intensively generated in the middle part of the specimen as visible cracks. Finally, the microcracks disperse. In pile M3 resulted in lightly damaged due to monotonic bending load, cracks are observed throughout the specimen as shown in M3 (a) and M3 (b).

In pile $\mathrm{S} 1$ resulted in heavily damaged due to monotonic shear load, microcracks are initially observed between the support and the loading point as shown in S1 (a). With load increase, the microcracks are spread in whole monitoring area as shown in S1 (b) and S1 (c). As for the crack classification, shear cracks are observed close to principle cracks in the center of the monitoring area, while tensile cracks surround these shear cracks.

In pile $\mathrm{S} 2$ resulted in heavily damaged due to monotonic shear load, tensile cracks are first generated in the right side of the observed area as shown in S2 (a), and then shear cracks are observed in the left side as shown in S2 (b). In cases of S1 and S2 resulted in heavily damaged due to shear load, shear cracks are macroscopically generated between the supports and the loading points. Actually, cracks due to bending are first observed directly below the loading points, and later the diagonal shear cracks 
CL
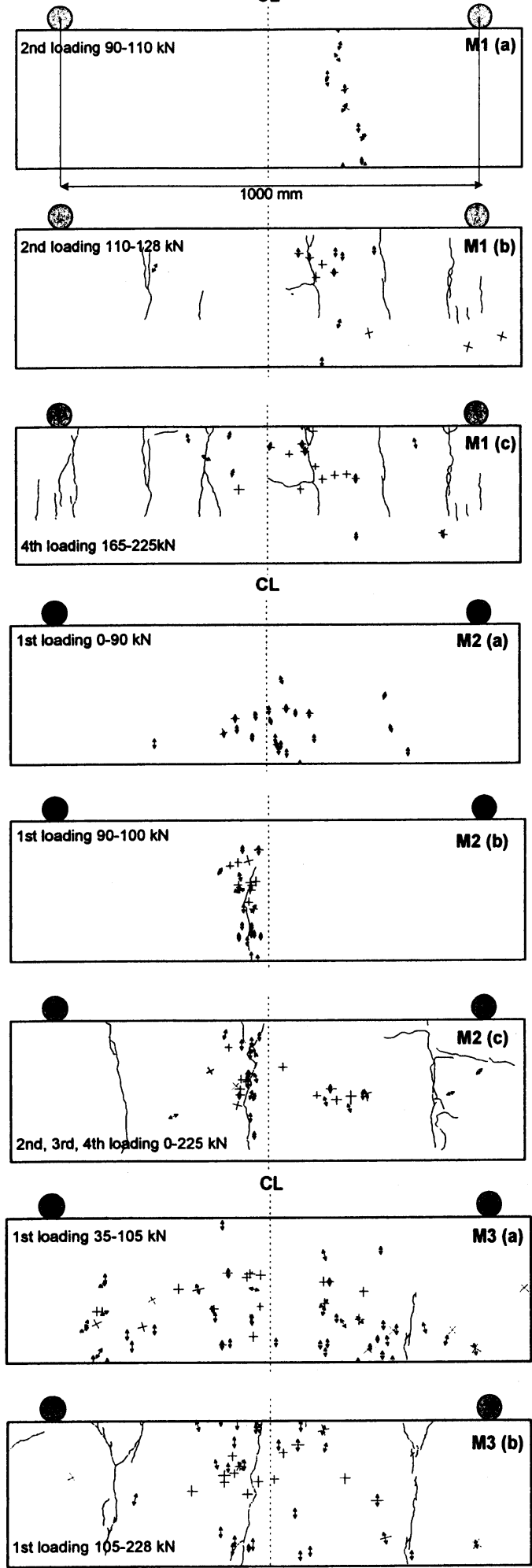

Fig. $5 \mathrm{AE}$ source location, crack classification and crack orientation in bending tests.
CL
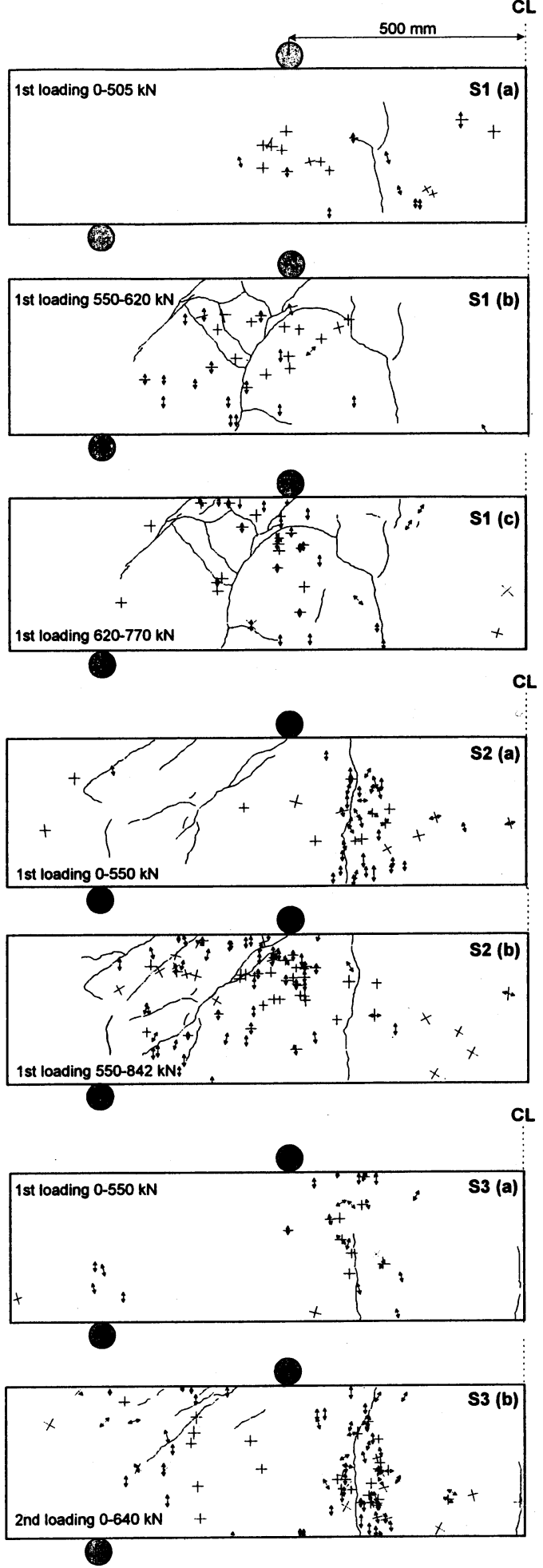

Fig. 6 AE source location, crack classification and crack orientation in shear tests. 
(1) M2: Before loading

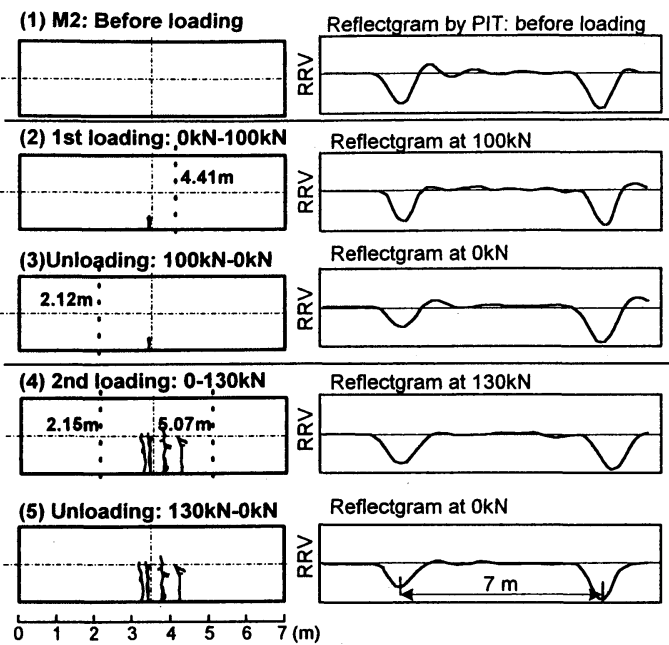

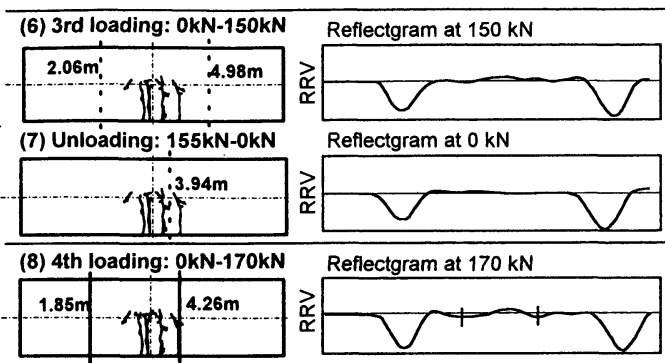

(9) 4th Loading: 170kN-200kN Reflectgram at $200 \mathrm{kN}$

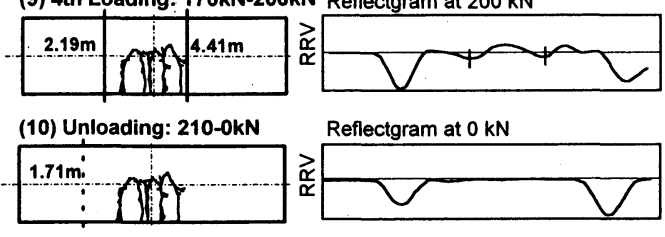

(11) 5th loading: $220 \mathrm{kN}-236 \mathrm{kN}$ Reflectgram at $236 \mathrm{kN}$

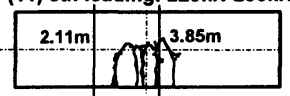

(12) Unloading: $236 \mathrm{kN}-0 \mathrm{kN}$

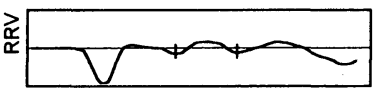

Reflectgram at OkN

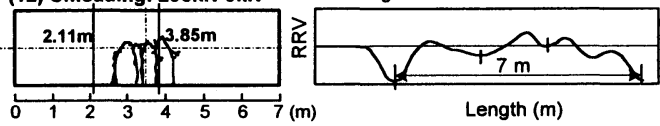

Fig. 7 Reflectogram of PIT and evaluated damage locations in pile M2 heavily damaged.

appear between the supports and the loading points. In pile $\mathrm{S} 3$ resulted in lightly damaged due to monotonic shear load, the same trend as heavily damaged piles is observed, although cracks in the left side are not so active as those of heavily damaged.

\section{(3) Pile integrity test}

PIT was carried out at each loading level as shown in Figs. 7 and 8. Fig. 7 shows results of pile M2 heavily damaged by the bending. The left graphs in the figure exhibit crack traces observed at each loading level. The right sides indicate records of velocity waves with time. The velocity waves are called "reflectogram" in PIT. Because the wave energy is easily attenuated with propagation, signals are amplified by an exponential function. Then, these amplified signals are divided by the input wave velocity. As a result, the amplitude of the waves is shown as the ratio of the relative velocity (RRV) as denoted in the graphs. In PIT, after hitting the pile head with a hammer, an elastic wave propagates through the pile. At the toe of the pile, the elastic wave is partially reflected, propagates back to the pile head and detected by a sensor. When the elastic wave propagates through the pile, another reflection occurs at the locations of damage. A reflected signal at the damaged location is evaluated as negative phase of the waveform. From the arrival time of the reflected wave, the location of damage in the pile is estimated. Those locations estimated are drawn by the vertical lines in the left sides of Figs. 7 and 8 , where solid lines show clear reflections and dotted lines show ambiguous reflections.

Figs. 7 (1) and 8 (1) show results of PIT for the pile with no damage. In Fig. 7 (2), the obvious reflection of the waveform is not observed even though the crack of $0.04 \mathrm{~mm}$ width exists at the center. After unloading, reflections of the wave are still not observed. From Fig. 7 (3) to Fig. 7 (7), clear reflections of the waves are still not found. At the fourth loading shown in Fig. 7 (8) at $170 \mathrm{kN}$ and (9) at $200 \mathrm{kN}$, reflected waves are evidently confirmed at $1.85 \mathrm{~m}$ and $4.26 \mathrm{~m}, 2.19 \mathrm{~m}$ and $4.41 \mathrm{~m}$, respectively. Although these damage locations estimated do not correspond to those of actual cracks, these results can identify the approximate range of the damage. After unloading, reflections of the wave disappear as shown in Fig. 7 (10). In the fifth loading reaching the final fracture at $236 \mathrm{kN}$ shown in Fig. 7 (11), obvious wave reflections are observed. After unloading, the pile once reaches the final fracture as shown in Fig. 7 (12), where distinguished reflections of the wave are found as the same as Fig. 7 (11). In the pile resulted in heavily damaged due to bending, 
(1) S3: Before Loading

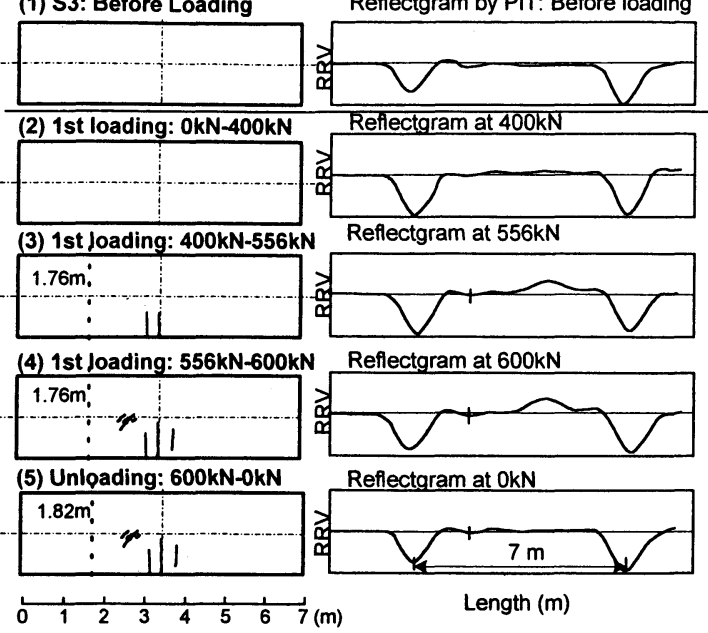

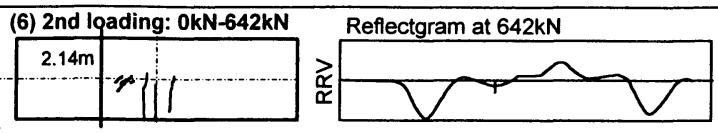

(7) 2nd lpading: $642 \mathrm{kN}-710 \mathrm{kN}$ Reflectgram at $710 \mathrm{kN}$

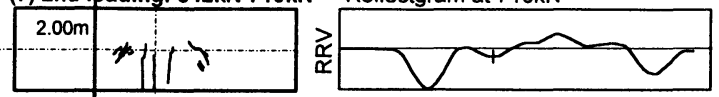

(8) 2nd Loading: $710 \mathrm{kN}-723 \mathrm{kN}$ Reflectgram at $723 \mathrm{kN}$

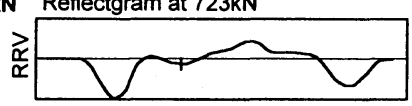

(9) Unloading: 723-0kN

Reflectgram at OkN

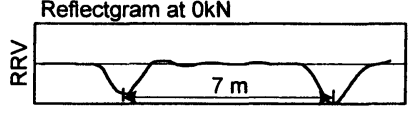

Length (m)

Fig. 8 Reflectogram of PIT and evaluated damage locations in pile S3 lightly damaged.

it is concluded that rough evaluation of the integrity is possible by PIT, although precise estimation of crack locations is difficult.

Fig. 8 shows the reflectogram of pile S3 resulted in lightly damaged due to cyclic shear load, obvious wave reflections are not observed until the load reaches $642 \mathrm{kN}$ as shown in Fig. 8 (6). Even though one crack location is evaluated, it does not agree with the locations of actual cracks. After unloading, there are no wave reflections as shown in Fig. 8 (9). In the case resulted in lightly damaged due to the shear load, it is concluded that an application of PIT to the diagnosis is not easy as similar to the case of pile which did not reach final failure due to the bending load shown from Fig. 7 (1) to Fig. 7 (10).

From the results of PIT in the bending tests, cracks are not successfully identified up to the loading level after $236 \mathrm{kN}$ in the forth loading where the crack width reaches $1.4 \mathrm{~mm}$. As for AE results in the same pile, the loading level giving unstable state of the pile exists between the second unloading and the third loading where the maximum crack width is between $0.08 \mathrm{~mm}$ and $0.30 \mathrm{~mm}$. It implies that $\mathrm{AE}$ is much more sensitive than PIT to evaluate the damage of piles.

\section{(4) Wave velocity}

In the case of PIT, when wave reflections from the toe of the pile are observed, wave velocity can be estimated from the relation between the pile length and the propagation time. Fig. 9 shows relations between the wave velocities and the measured crack widths in piles $\mathrm{M} 1$ and $\mathrm{S} 2$. For the pile M1 subjected to bending load, the velocity starts to drop at crack width of $0.08 \mathrm{~mm}$, and further decreases up to the crack width around $0.2 \mathrm{~mm}$. For the pile S2 subjeccted to shear loading, the maximum crack width is smaller than that of the bending. However, onset of the velocity decrease is the same as the bending, and the width where the velocity significantly decreases is identical. In contrast, crack widths that show unstable state evaluated from Felicity ratio and the cumulative $\mathrm{AE}$ ratio are $0.08-0.30 \mathrm{~mm}$ for the bending and $0.15-0.20 \mathrm{~mm}$ for the shear loadings, respectively. Thus, the results of $\mathrm{AE}$ agree quite well with those of the wave velocity.

Consequently, when the wave velocity in intact state ot the concrete-piles is known, the wave velocity can provide useful information on the pile integrity, although the precise estimation of damaged locations are very difficult. In the case of the accurate investigation of crack condition, which is essential for repair works, the $\mathrm{AE}$ technique would be more promising.

\section{CONCLUSIONS}

A fundamental study on fracture mechanisms of full-scale prestressed high-strength concrete (PHC) piles under both cyclic and monotonic loadings was carried out by applying AE technique. Also applying PIT, the applicability of both techniques to damage diagnosis was discussed. The results lead to the following conclusions:

(1) The crack width of unstable failure evaluated by $\mathrm{AE}$ technique ranges $0.08-0.30 \mathrm{~mm}$ for the bending load, while that ranges $0.15-0.20 \mathrm{~mm}$ for the shear 


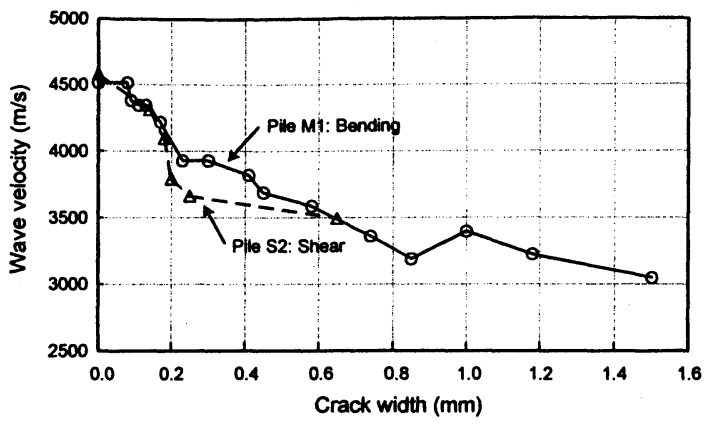

Fig. 9 Wave velocity estimated by PIT results in piles M1 and S2.

load. These results on the crack width were compatible to those of reinforced concrete.

(2) Because cracks in PHC piles of the width smaller than $0.5 \mathrm{~mm}$ under loading would close after unloading, it is difficult to evaluate structural integrity of the piles from only the width of surface crack. By Felicity ratio and the cumulative $\mathrm{AE}$ ratio, structural integrity of the PHC piles can be evaluated.

(3) In the heavily damaged piles due to bending, rough evaluation of the integrity by PIT is possible, whereas precise estimation of crack location is not easy.

(4) In the lightly damaged piles due to both shear and bending, PIT is not readily applicable to the evaluation of structural integrity.

(5) To evaluate the damage of piles, AE was much more sensitive than PIT. In addition, AE results were in good agreement with those of the wave velocity.

\section{REFERENCES}

1) Middendorp, P. and Reiding, F. J.: Determination of discontinuities in piles by TNO integrity testing and signal matching techniques, Proc. of the 3rd Int. Conf. on the Appl. of Stress-Wave Theory to Piles, pp.33-43 1988.

2) Tsukada, Y. and Ichimura, Y.: Application of Integrity Tests for Quality Control of Cast-In-Siu Piles, J. Geotech. Eng., JSCE, No. 603 / III-44, pp.139-146, 1998. (in Japanese)

3) Ohtsu, M.: History and Development of Acoustic Emission in Concrete Engineering, J. Materials, Conc. Struct., Pavements, JSCE, No. 496 / V-24, pp.9-19, 1994. (in Japanese)

4) Mori, S. and Shiotani, T.: Development of a New Inspection Method for Concrete Piles Damaged due to Earthquakes by Acoustic Emission, J. Strct. Mech. Earthquake Eng., JSCE, No. 605 / I-45 pp. 61-77, 1998.10. (in Japanese)

5) Shiotani, T., Sakaino, N., Ohtsu, M. and Shigeishi, M.: Damage Diagnosis of Concrete Piles after Earthquakes by Acoustic Emission, Proc. Forth Far East Conf. on Nondestr.
Testing, KSNT, pp. 579-588, 1997.

6) Ohtsu, M.: Simplified Moment Tensor Analysis and Unified Decomposition of AE Source, J. Geophysical Research, 96 (B), pp. 6211-6221, 1991.

7) Yuyama, S., Okamoto, T., Shigeishi, M. and Ohtsu, M.: Cracking Progress Evaluation in Reinforced Concrete by Moment Tensor Analysis of Acoustic Emission, J. Acoustic Emission, 13(1/2), s14-s20, 1995.

8) Ohtsu, M.: Rate Process Analysis of Acoustic Emission Activity in Core Test of Concrete, Proc. of JSCE No. 442/V-16, pp. 211-217, 1992.

9) Yuyama, S., Okamoto, T., Shigeishi, M., Ohtsu, M. and Kishi, T.: A Proposed Standard for Evaluating Structural Integrity of Reinforced Concrete Beams by Acoustic Emission, Acoustic Emission: Standards and Technology Update, ASTM STP 1353, pp. 25-40, 1999.

10) Yuyama, S., Okamoto, T., Shigeishi, M. and Ohtsu, M.: Quantitative Evaluation and Visualization of Cracking Process in Reinforced Concrete by a Moment Tensor Analysis of Acoustic Emission, Materials Evaluation, ASNT, Vol. 53, No. 6, pp. 751-756, 1994.

11) Yuyama, S., Okamoto, T., Shigeishi, M. and Ohtsu, M.: Acoustic Emission Generated in Comers of Reinforced Concrete Rigid Frame Under Cyclic Loading, Materials Evaluation, ASNT, Vol. 53, No.3, pp. 409-412, 1994.

12) Leonhardt, F.: Vorlesungen Über Massivbau Vol. 5, Springer-Verlag, 1980, translated by Narui, M., et al., Kajima Inst Pub., 1983.

13) Knopoff, L. and Randall, M. J.: The Compensated Linear Vector Dipole: A Possible Mechanism for Deep Earthquake J. Geophysical Research, 75 (26), pp. 4957-4963, 1970.

(Received June 4, 1999) 


\section{プレストレストコンクリート杭の \\ アコースティック・エミッションによる損傷評価 \\ 塩谷智基 · 重石光弘 - 大津政康}

単調載荷および繰返し載荷時の実PHC杭の曲げ・せん断試験にAE法を適用した．破壊にともなう損傷 の進行過程を AEによりモニタリングし, AE発生源の三次元位置標定および, クラックの種別・方向を SiGMA解析により決定した. これらの結果をPIT試験や目視観察結果と比較し, AEによるPC杭の損傷評価 の適用性を検討した. その結果, PITは, PHC杭が破断に至っていない,つまり，載荷過程で生じたクラッ クが閉口する場合，その損佰評価への適用は困難であることが明らかとなった. 一方，AE計測は，そのよ うな場合にもPC杭の損伤評価が可能で, 曲げ供試体では, 0.08-0.30 mm, せん断供試体では0.15-0.20 mmの クラック幅を有する損傷から評価できることが明らかとなった. 